\title{
EFFECT OF $5 \alpha$-DIHYDROPROGESTERONE, PREGN-5-ENE-3,20-DIONE, PREGNENOLONE AND RELATED PROGESTINS ON OVULATION IN PMSG-TREATED IMMATURE RATS
}

\author{
B. N. SRIDHARAN, R. K. MEYER AND H. J. KARAVOLAS \\ Departments of Zoology and Physiological Chemistry, \\ The Endocrinology-Reproductive Physiology Program, University of Wisconsin, \\ Madison, Wisconsin 53706, U.S.A.
}

(Received 9th January 1973)

\begin{abstract}
Summary. The facilitative effects of certain progestational steroids on ovulation were investigated by using 25-day-old female rats which had been treated on Day 22 with a non-ovulatory dose of PMSG (12 i.u.). Ovulation was caused by treatment with pregnenolone or progesterone on the morning of Day 24. The dose of pregnenolone required was higher than that of progesterone. Progesterone had this effect throughout the morning of Day 24, while prenenolone was only effective between 07.00 and 10.00 hours on Day 24. The two metabolites of progesterone in the hypothalamus and uterus, $5 \alpha$-dihydroprogesterone and $3 \alpha$ hydroxy- $5 \alpha$-pregnan-20-one, were also tested for their ability to cause ovulation. Although $5 \alpha$-dihydroprogesterone possessed this ability, a dose three to four times that of progesterone was required to produce a comparable effect. Doses of up to $1.5 \mathrm{mg} 3 \alpha$-hydroxy- $5 \alpha$-pregnan-20-one were without effect. Neither $17 \alpha$-hydroxypregnenolone nor $17 \alpha$-hydroxyprogesterone had any effect in influencing ovulation.

Pregn-5-ene-3,20-dione had a facilitative ability comparable to that of progesterone in doses of $0.25 \mathrm{mg}$ or higher. The facilitative effect of progesterone decreased when it was injected earlier on Day 24 or during the evening of Day 23; no potentiating effect was obtained at 14.00 hours on Day 23. The results obtained with pregnenolone, progesterone and related steroids support the hypothesis that the inhibition of ovulation by phenobarbital may be due in part to its interference with the conversion of pregnenolone to pregn-5-ene-3,20-dione.
\end{abstract}

\section{INTRODUCTION}

The ability of progesterone to influence ovulation in rats is well recognized although the mechanisms involved are not well understood (Zarrow \& Hurlbut, 1967; Caligaris, Astrada \& Taleisnik, 1968; Zarrow \& Gallo, 1969; Arimura \& Schally, 1970). McCormack \& Meyer (1962) showed that progesterone on Day 24 increased the incidence of ovulation in rats when they had been given 
a single dose of 15 i.u. PMSG on Day 22. In rats of the same age treated with 3 i.u. PMSG, Ying \& Meyer (1969a) demonstrated that progesterone will advance ovulation by $24 \mathrm{hr}$ when given at 10.00 hours on Day 23 but will postpone ovulation by 24 or $48 \mathrm{hr}$ when given on Day 22 .

It has been shown by many workers that phenobarbital (PB) and other neuropharmacological agents will block ovulation when given before the critical period on the day of pro-oestrus in adults or PMSG-primed immature rats (Everett \& Sawyer, 1950; Strauss \& Meyer, 1962; Zarrow \& Brown-Grant, 1964). This block of ovulation could be prevented if progesterone was given before the PB treatment. In 22-day-old rats treated with 3 i.u. PMSG, Ying \& Meyer (1969c) blocked ovulation by injection of PB on Day 24. An injection of progesterone did restore ovulation, but injection of pregnenolone acetate in doses up to $4 \mathrm{mg}$ did not restore ovulation in these rats.

Meyer, Karavolas, Klausing \& Norgard (1971) reported that rats treated with PB and primed with PMSG showed a decrease in plasma progesterone levels and an increase in the levels of pregnenolone, suggesting that PB inhibits the conversion of pregnenolone to progesterone. These findings were supported and extended by the work of Karavolas, Gupta \& Meyer (1972). They reported that, when incubated with $\left[{ }^{14} \mathrm{C}\right]$ cholesterol, ovaries removed from animals treated with $\mathrm{PB}$ showed an increased accumulation of pregnenolone as compared with ovaries from animals not treated with PB. Phenobarbital added directly, in vitro, to the ovarian tissue had no detectable effect on the production of the various steroids examined. The data suggested that PB either decreases the enzymatic conversion of pregnenolone to progesterone or alters some endogenous factor necessary for this conversion (Karavolas et al., 1972).

Gupta \& Karavolas (1973), in their work on the ovaries of PMSG-treated immature rats, proposed that the intermediate compound in the conversion of pregnenolone to progesterone in the rat ovary is pregn-5-ene-3,20-dione, thereby suggesting that the first enzyme to act on pregnenolone is $3 \beta$-hydroxysteroid dehydrogenase and is followed by the action of $\Delta^{4-5}$ isomerase as has been shown with other steroidogenic tissues and species (Cheatum \& Warren, 1960; Ewald, Werbin \& Chaikoff, 1964; Cheatum, Douville \& Warren, 1967). Furthermore, they suggested that the activity of $3 \beta$-hydroxysteroid dehydrogenase is affected by treatment with $\mathrm{PB}$ as they recovered lower amounts of ${ }^{14} \mathrm{C}$ associated with pregn-5-ene-3,20-dione in the PB-treated groups. If this interference by $\mathrm{PB}$ with the conversion of pregnenolone to progesterone and its subsequent metabolites affects the optimal steroidal environment essential for the regulation of ovulation, then it should be possible to demonstrate the ability of pregnenolone to facilitate ovulation in a test system where PB is not present. Such a test system is provided by the 22-day-old rats treated with $12 \mathrm{i}$.u. PMSG where the incidence of spontaneous ovulation is low (Ying \& Meyer, 1969b; Ying, 1969). McCormack \& Meyer (1964) showed that a small dose of progesterone in these animals would cause ovulation in $100 \%$ of the animals. In these animals, pregnenolone administration should, by virtue of its conversion into progesterone, induce ovulation.

Karavolas \& Herf (1971) and Cheng \& Karavolas (1973) conducted studies on the uptake and metabolism of labelled progesterone in the medial basal 
hypothalamus of rats in pro-oestrus. They reported that progesterone was converted into two metabolites, $5 \alpha$-dihydroprogesterone ( $5 \alpha$-pregnan-3,20dione) and $3 \alpha$-hydroxy-5 $\alpha$-pregnan-20-one. Interestingly, the same two steroids had been reported by Armstrong \& King (1971) and Wiest (1963) to be the principal metabolites of progesterone in the uterine tissue.

This report describes the results obtained when pregnenolone, progesterone and related metabolites were examined for the facilitative action in 22-day-old rats treated with a non-ovulatory dose of PMSG.

\section{MATERIALS AND METHODS}

Twenty-one-day-old rats were received from Holtzman Co., Madison, Wisconsin, and were maintained on Rockland rat chow and water. The animal room was kept between 75 and $80^{\circ} \mathrm{F}$. A subcutaneous injection of 12 i.u. PMSG (Equinex, Ayerst Laboratories, Chicago, Ill.) in $0.25 \mathrm{ml} 0.9 \% \mathrm{NaCl}$ was given at 22 days of age, between 07.00 and 08.00 hours. The steroids were given in 0.2 to $0.5 \mathrm{ml}$ corn oil USP (Magnus, Maybee and Reynard Inc., New York) at various times as specified in the tables. Controls were treated with corn oil only. (The sources of the steroids used were: pregnenolone, progesterone, 17 $\alpha$-hydroxypregnenolone, $17 \alpha$-hydroxyprogesterone and $5 \alpha$ dihydroprogesterone from Sigma Chemical Co., St. Louis, Mo.; pregn-5ene-3,20-dione from Steraloids Inc., New York, N.Y.; $3 \alpha$-hydroxy- $5 \alpha$-pregnan20-one from Ikapharm, Ramet-Gan, Israel.) The purity of all the steroids had been verified by thin-layer and gas chromatography (Karavolas \& Herf, 1971; Karavolas et al., 1972; Gupta \& Karavolas, 1973). The lighting consisted of a 14-hr light (05.00 to 19.00 hours CST)/10-hr dark regimen.

Animals were killed on Day 25 with an overdose of ether. The oviducts were removed and compressed between two glass slides and the ova were counted under magnification. The ovaries were dissected free of fat and were weighed on a Mettler balance to the nearest $0.5 \mathrm{mg}$. The data were analysed using Student's $t$ test and the $\chi^{2}$ test.

\section{RESULTS}

Progesterone $(0.5 \mathrm{mg})$ induced ovulation in all the rats treated with 12 i.u. PMSG (Table 1). None of the control rats ovulated. When the animals were injected with $0.5 \mathrm{mg}$ pregnenolone at 10.00 hours there was no ovulation in five animals; one of five ovulated when pregnenolone was injected at 06.00 hours.

To test the possibility that a larger dose of pregnenolone given earlier during the day would cause ovulation, a second experiment was conducted (Table 2). In this experiment, a larger dose of pregnenolone $(1.5 \mathrm{mg})$ was given at intervals beginning at 22.00 hours on Day 23 to 13.00 hours on Day 24 .

When pregnenolone was given at 10.00 hours on Day $24,80 \%$ of the animals ovulated. Of the two groups that were injected at 07.00 hours, $80 \%$ in one group ovulated and $60 \%$ in the other group. When injections were made at other times, the incidence was not much higher than controls. Thus, the optimal time 
Table 1. Effect of pregnenolone and progesterone in facilitating ovulation on Day 25 in rats treated with PMSG*

\begin{tabular}{|c|c|c|c|c|c|}
\hline Treatment & $\begin{array}{l}\text { Time of } \\
\text { injection } \\
\text { (Day 24) }\end{array}$ & $\begin{array}{c}\text { No. of rats } \\
\text { ovulating }\end{array}$ & $\stackrel{\%}{\%}$ ovulation & $\begin{array}{l}\text { Av. no. of oval } \\
\text { ovulating rat } \\
\quad \pm \text { S.E. }\end{array}$ & $\begin{array}{c}\text { Av. ovarian w } \\
(m g) \pm S . E .\end{array}$ \\
\hline $\begin{array}{l}\text { Controls } \\
\text { Pregnenolone } \\
\text { Pregnenolone } \\
\text { Progesterone }\end{array}$ & $\begin{array}{l}10.00 \text { hours } \\
06.00 \text { hours } \\
10.00 \text { hours }\end{array}$ & $\begin{array}{l}0 / 5 \\
0 / 5 \\
1 / 5 \\
5 / 5\end{array}$ & $\begin{array}{r}0 \\
0 \\
20 \\
100\end{array}$ & $\begin{array}{c}\overline{\overline{14}} \\
44 \cdot 0 \pm 4 \cdot 0\end{array}$ & $\begin{array}{c}78 \cdot 8 \pm 7 \cdot 1 \\
73 \cdot 8 \pm 6 \cdot 4 \\
67 \cdot 2 \pm 11 \cdot 8 \\
115 \cdot 0 \pm 9 \cdot 0\end{array}$ \\
\hline
\end{tabular}

* All animals were injected with 12 i.u. PMSG on Day 22 between 07.00 and 08.00 hours. The steroids $(0.5 \mathrm{mg}$ in corn oil) were injected on Day 24 at specified times.

Table 2. Effect of pregnenolone and progesterone on facilitation of ovulation on Day 25 in rats treated with 12 i.u. PMSG

\begin{tabular}{|c|c|c|c|c|c|c|}
\hline Treatment* & Day & Time & $\begin{array}{l}\text { No. of rats } \\
\text { ovulating }\end{array}$ & $\begin{array}{c}\% \\
\text { ovulation }\end{array}$ & $\begin{array}{l}\text { Av. no. of oval } \\
\text { ovulating rat } \\
\pm S . E .\end{array}$ & $\begin{array}{l}\text { Av. ovarian wt } \\
(m g) \pm S . E .\end{array}$ \\
\hline Controls & - & - & $\begin{array}{l}2 / 6 \\
1 / 6\end{array}$ & $\begin{array}{l}33 \\
17\end{array}$ & $\begin{array}{l}16 \cdot 0 \pm 1 \cdot 0 \\
28 \cdot 0\end{array}$ & $\begin{array}{l}76 \cdot 8 \pm 3 \cdot 6 \\
97 \cdot 4 \pm 6 \cdot 4\end{array}$ \\
\hline Pregnenolone & $\begin{array}{l}23 \\
24 \\
24 \\
24 \\
24 \\
24\end{array}$ & $\begin{array}{l}22.00 \text { hours } \\
01.00 \text { hours } \\
04.00 \text { hours } \\
06.00 \text { hours } \\
07.00 \text { hours } \\
10.00 \text { hours }\end{array}$ & $\begin{array}{l}2 / 5 \\
1 / 5 \\
2 / 5 \\
3 / 5 \\
4 / 5 \\
3 / 5 \\
4 / 5\end{array}$ & $\begin{array}{l}40 \\
20 \\
40 \\
60 \\
80 \\
60 \\
80\end{array}$ & $\begin{array}{l}40 \cdot 5 \pm 8 \cdot 5 \\
38 \cdot 0 \\
43 \cdot 5 \pm 9 \cdot 3 \\
35 \cdot 3 \pm 9 \cdot 1 \\
32 \cdot 5 \pm 10 \cdot 1 \\
28 \cdot 3 \pm 10 \cdot 7 \\
31 \cdot 0 \pm 6 \cdot 8\end{array}$ & $\begin{array}{l}77 \cdot 3 \pm 9 \cdot 0 \\
65 \cdot 0 \pm 8 \cdot 2 \\
88 \cdot 5 \pm 8 \cdot 9 \\
98 \cdot 0 \pm 8 \cdot 7 \\
89 \cdot 3 \pm 9 \cdot 5 \\
73 \cdot 0 \pm 6 \cdot 7 \\
88 \cdot 0 \pm 8 \cdot 4\end{array}$ \\
\hline Progesterone & $\begin{array}{l}23 \\
24 \\
24 \\
24 \\
\\
24 \\
24\end{array}$ & $\begin{array}{l}22.00 \text { hours } \\
01.00 \text { hours } \\
04.00 \text { hours } \\
07.00 \text { hours } \\
10.00 \text { hours } \\
13.00 \text { hours }\end{array}$ & $\begin{array}{l}5 / 5 \\
4 / 5 \\
5 / 5 \\
5 / 5 \\
5 / 5 \\
5 / 5 \\
5 / 5\end{array}$ & $\begin{array}{r}100 \\
80 \\
100 \\
100 \\
100 \\
100 \\
100\end{array}$ & $\begin{array}{l}19 \cdot 4 \pm 5 \cdot 7 \\
30 \cdot 0 \pm 8 \cdot 6 \\
45 \cdot 0 \pm 3 \cdot 4 \\
40 \cdot 8 \pm 7 \cdot 8 \\
45 \cdot 6 \pm 7 \cdot 5 \\
49 \cdot 2 \pm 13 \cdot 4 \\
59 \cdot 2 \pm 13 \cdot 8\end{array}$ & $\begin{array}{c}75 \cdot 0 \pm 3 \cdot 8 \\
87 \cdot 8 \pm 8 \cdot 2 \\
90 \cdot 5 \pm 10 \cdot 5 \\
79 \cdot 7 \pm 3 \cdot 1 \\
147 \cdot 2 \pm 14 \cdot 7 \\
96 \cdot 2 \pm 9 \cdot 4 \\
97 \cdot 0 \pm 9 \cdot 2\end{array}$ \\
\hline
\end{tabular}

* The steroids (1.5 $\mathrm{mg}$ in corn oil) were injected subcutaneously.

Table 3. Absence of the facilitative effect of progesterone when given in the afternoon of Day 23 to rats treated with 12 i.u. PMSG

\begin{tabular}{|c|c|c|c|c|c|c|}
\hline Treatment* & Day & Time & $\begin{array}{l}\text { No. of rats } \\
\text { ovulating }\end{array}$ & $\begin{array}{c}\% \\
\text { ovulation }\end{array}$ & $\begin{array}{l}\text { Av. no. of oval } \\
\text { ovulating rat } \\
\pm S . E .\end{array}$ & $\begin{array}{l}\text { Av. ovarian wt } \\
(m g) \pm S . E\end{array}$ \\
\hline $\begin{array}{l}\text { Controls } \\
\text { Progesterone } \\
\text { Progesterone } \\
\text { Progesterone }\end{array}$ & $\begin{array}{l}\overline{23} \\
23 \\
24\end{array}$ & $\begin{array}{l}14.00 \text { hours } \\
18.00 \text { hours } \\
10.00 \text { hours }\end{array}$ & $\begin{array}{l}1 / 5 \\
0 / 6 \\
1 / 6 \\
6 / 6\end{array}$ & $\frac{20}{17}$ & $\begin{array}{c}6 \cdot 0 \\
\overrightarrow{32 \cdot 0} \\
42 \cdot 0 \pm 8 \cdot 2\end{array}$ & $\begin{array}{l}62 \cdot 8 \pm 7 \cdot 8 \\
79 \cdot 8 \pm 6 \cdot 3 \\
87 \cdot 6 \pm 4 \cdot 5 \\
89 \cdot 2 \pm 10 \cdot 8\end{array}$ \\
\hline
\end{tabular}

* Progesterone ( $1.5 \mathrm{mg}$ in corn oil) was injected at the specified times. 
for administration of pregnenolone for its facilitatory effect on ovulation is between 07.00 and 10.00 hours on Day 24 .

Analysis of the data obtained in animals treated with progesterone at various times (Table 2) shows that the ovulation rate was high, but there was a difference in the number of ova ovulated per animal in various groups. At 13.00 hours on Day 24, the average number of ova ovulated per animal was $59 \cdot 0$. At 10.00 hours on Day 24, it was 49.0 and at 07.00 hours it was 40.8 and 45.6 and progressively reached to 19.4 at 22.00 hours on Day 23 . The differences between the numbers of ova were not statistically significant. Table 3 shows

Table 4. Effect of $17 \alpha$-hydroxypregnenolone, $17 \alpha$-hydroxy-progesterone, $5 \alpha$-dihydroprogesterone and $3 \alpha$-hydroxy- $5 \alpha$-pregnan20 -one in facilitating ovulation on Day 24 in rats treated with 12 i.u. PMSG

\begin{tabular}{|c|c|c|c|c|c|}
\hline Treatment* & $\underset{(m g)}{A m o u n t}$ & $\begin{array}{l}\text { No. of rats } \\
\text { ovulating }\end{array}$ & $\stackrel{\%}{\%}$ & $\begin{array}{l}\text { Av. no. of oval } \\
\text { ovulating rat } \\
\quad \pm S . E .\end{array}$ & $\begin{array}{l}A v . \text { ovarian wt } \\
(m g) \pm S . E .\end{array}$ \\
\hline Controls & - & $\begin{array}{l}0 / 6 \\
0 / 6 \\
0 / 6\end{array}$ & $\begin{array}{l}0 \\
\mathbf{0} \\
0\end{array}$ & - & $\begin{array}{l}88 \cdot 5 \pm 5 \cdot 1 \\
54 \cdot 6 \pm 1 \cdot 5 \\
61 \cdot 8 \pm 5 \cdot 1\end{array}$ \\
\hline $\begin{array}{l}17 \alpha \text {-Hydroxy- } \\
\text { pregnenolone }\end{array}$ & $\begin{array}{l}1 \cdot 5 \\
3 \cdot 0\end{array}$ & $\begin{array}{l}0 / 6 \\
0 / 3\end{array}$ & $\begin{array}{l}0 \\
0\end{array}$ & - & $\begin{array}{l}57 \cdot 6 \pm 6 \cdot 5 \\
53 \cdot 7 \pm 1 \cdot 2\end{array}$ \\
\hline $\begin{array}{l}17 \alpha \text {-Hydroxy- } \\
\text { progesterone }\end{array}$ & $\begin{array}{l}0.45 \\
1.5\end{array}$ & $\begin{array}{l}0 / 5 \\
1 / 6\end{array}$ & $\begin{array}{r}0 \\
17\end{array}$ & $\overline{7}$ & $\begin{array}{l}68 \cdot 5 \pm 6 \cdot 6 \\
63 \cdot 5 \pm 7 \cdot 4\end{array}$ \\
\hline $\begin{array}{l}5 \alpha \text {-Dihydro- } \\
\text { progesterone }\end{array}$ & $\begin{array}{l}0.5 \\
1.5 \\
2 \cdot 0\end{array}$ & $\begin{array}{l}1 / 5 \\
5 / 5 \\
5 / 5\end{array}$ & $\begin{array}{r}20 \\
100 \\
100\end{array}$ & $\begin{array}{c}15 \\
33 \cdot 6 \pm 6 \cdot 6 \\
22 \cdot 4 \pm 3 \cdot 5\end{array}$ & $\begin{array}{r}97.8 \pm 11.2 \\
115 \cdot 6 \pm 13 \cdot 8 \\
102.2 \pm 10 \cdot 4\end{array}$ \\
\hline $\begin{array}{l}3 \alpha \text {-Hydroxy- } \\
5 \alpha \text {-pregnan- } \\
20 \text {-one }\end{array}$ & $\begin{array}{l}0.5 \\
1.5\end{array}$ & $\begin{array}{l}1 / 5 \\
0 / 5\end{array}$ & $\begin{array}{r}20 \\
0\end{array}$ & 11 & $\begin{array}{l}61 \cdot 2 \pm 5 \cdot 9 \\
53 \cdot 0 \pm 5 \cdot 0\end{array}$ \\
\hline
\end{tabular}

* Steroids in corn oil were injected at 10.00 hours on Day 24.

Table 5. Facilitatory effect of progesterone and pregn-5-ene-3,20dione on ovulation when given on Day 24 to immature rats treated with 12 i.u. PMSG

\begin{tabular}{|c|c|c|c|c|c|}
\hline Treatment* & $\underset{(m g)}{A m o u n t}$ & $\begin{array}{c}\text { No. of rats } \\
\text { ovulating }\end{array}$ & $\begin{array}{l}\% \\
\text { ovulation }\end{array}$ & $\begin{array}{l}\text { Av. no. of oval } \\
\text { ovulating rat } \\
\pm S . E .\end{array}$ & $\begin{array}{l}\text { Av. ovarian wt. } \\
(m g) \pm S . E .\end{array}$ \\
\hline Controls & & $0 / 5$ & 0 & 一 & $67 \cdot 8 \pm 7 \cdot 7$ \\
\hline Progesterone & $\begin{array}{l}0.031 \\
0.063 \\
0 \cdot 125 \\
0.25 \\
0.5 \\
1 \cdot 0\end{array}$ & $\begin{array}{l}2 / 4 \\
2 / 4 \\
3 / 4 \\
5 / 5 \\
5 / 5 \\
5 / 5\end{array}$ & $\begin{array}{r}50 \\
50 \\
75 \\
100 \\
100 \\
100\end{array}$ & $\begin{array}{l}30.0 \pm 2.0 \\
12.0 \pm 0.0 \\
14.6 \pm 5.6 \\
35.0 \pm 8.8 \\
53.0 \pm 5.5 \\
40.2 \pm 3.8\end{array}$ & $\begin{array}{c}87 \cdot 3 \pm 13 \cdot 1 \\
92 \cdot 0 \pm 14 \cdot 1 \\
118 \cdot 8 \pm 7 \cdot 9 \\
79 \cdot 5 \pm 3 \cdot 4 \\
93 \cdot 0 \pm 5 \cdot 3 \\
90 \cdot 2 \pm 6 \cdot 2\end{array}$ \\
\hline $\begin{array}{l}\text { Pregn-5-ene- } \\
\text { 3,20-dione }\end{array}$ & $\begin{array}{l}0.031 \\
0.063 \\
0.125 \\
0.125 \\
0.25 \\
0.5\end{array}$ & $\begin{array}{l}0 / 4 \\
2 / 4 \\
2 / 4 \\
2 / 5 \\
5 / 5 \\
5 / 5\end{array}$ & $\begin{array}{r}0 \\
50 \\
50 \\
40 \\
100 \\
100\end{array}$ & $\begin{array}{l}34.5 \pm 1 \cdot 5 \\
35.5 \pm 1.5 \\
48.5 \pm 19 \cdot 5 \\
39 \cdot 0 \pm 11.9 \\
33.8 \pm 8 \cdot 1\end{array}$ & $\begin{array}{l}78 \cdot 5 \pm 6 \cdot 8 \\
81 \cdot 5 \pm 4 \cdot 0 \\
90 \cdot 0 \pm 4 \cdot 6 \\
73 \cdot 0 \pm 3 \cdot 9 \\
81 \cdot 4 \pm 4 \cdot 7 \\
87 \cdot 7 \pm 3 \cdot 4\end{array}$ \\
\hline
\end{tabular}

* Steroids in corn oil were injected at 10.00 hours on Day 24. 
the results when two groups of rats were injected with progesterone on Day 23. The rate of ovulation decreased to $20 \%$ when progesterone was given at 18.00 hours on Day 23 and the facilitative effect of progesterone was absent or there was an inhibitory effect when the steroid was injected at 14.00 hours.

The potentiating action of $17 \alpha$-hydroxypregnenolone and $17 \alpha$-hydroxyprogesterone was tested and the results are shown in Table 4. Neither steroid appeared to have any facilitative effect. Injections of 1.5 and $2.0 \mathrm{mg} 5 \alpha-$ dihydroprogesterone caused ovulation in all the treated animals (Table 4), but $3 \alpha$-hydroxy- $5 \alpha$-pregnan-20-one did not have any effect.

The steroid, pregn-5-ene-3,20-dione, was found to have a strong facilitative action (Table 5). A comparison with the effects of equal doses of progesterone shows that the action of pregn-5-ene-3,20-dione was equal to that of progesterone in doses of $0.25 \mathrm{mg}$ or higher. In lower doses, progesterone appeared to have a slightly greater effect than pregn-5-ene-3,20-dione, but the difference was not statistically significant $\left(\chi^{2}=1 \cdot 72, P>0 \cdot 1\right)$.

\section{DISCUSSION}

The mechanism(s) by which PB and other neuropharmacological agents inhibit ovulation in PMSG-primed immature rats has been postulated by Ying \& Meyer (1969c) to be due probably to their interference with the metabolism and/or synthesis of steroids essential for the neural regulation of ovulation or an alteration of thresholds of excitability in the hypothalamus which controls the release of the gonadotrophin necessary for ovulation.

Animals treated with PB show reduced amounts of progesterone and higher amounts of pregnenolone in the blood (Meyer et al., 1971). Injection of pregnenolone did not cause ovulation in these PB-treated animals while small amounts of progesterone overcame PB-block of ovulation (B. N. Sridharan, R. K. Meyer and H. J. Karavolas, unpublished data).

In the experiments reported in this paper, by using a test system without PB and thereby eliminating the inhibitory effects caused by $\mathrm{PB}$, we have tested the ability of pregnenolone to facilitate ovulation and found positive effects. We interpret the data to mean that the effect of pregnenolone is due to its conversion into progesterone. The fact that pregnenolone had to be administered in large doses and within specific time-limits for optimal facilitative action as well as the inability of pregnenolone to cause ovulation in the PB-treated animals (B. N. Sridharan, R. K. Meyer and H. J. Karavolas, unpublished data) supports this view.

While pregnenolone facilitated ovulation when given at the appropriate time and dose (1.5 mg at 10.00 hours on Day 24), 17 $\alpha$-hydroxypregnenolone and $17 \alpha$-hydroxyprogesterone did not have any facilitative action. This indicates that a hydroxyl group attached at C-17 of the cyclopentane ring eliminates the ovulation-inducing ability. Swerdloff, Jacobs \& Odell (1972) observed that $17 \alpha$-hydroxyprogesterone did not have any synergistic or independent effect in LH or FSH surge in the ovariectomized oestrogen-primed rats. They noted, however, that, in humans, $17 \alpha$-hydroxyprogesterone as a 'progestagen' may play a facilitatory rôle in LH-FSH preovulatory surge. 
The two principal metabolites of progesterone were tested to determine whether either could account for the activity of the original compound. The $3 \alpha$-hydroxy- $5 \alpha$-pregnan-20-one metabolite had no facilitative action, but $5 \alpha$ dihydroprogesterone did induce ovulation though it was less potent than progesterone. Bosley \& Leavitt (1972) also reported that, in hamsters, $5 \alpha$ dihydroprogesterone showed facilitative action but was less potent than progesterone.

By far the strongest activity was shown by progesterone and pregn-5-ene3,20-dione. Evidence was presented recently (Gupta \& Karavolas, 1973) that pregn-5-ene-3,20-dione was the intermediate between pregnenolone and progesterone in the rat ovary. This compound had an effect equal to that of progesterone in levels of $0.25 \mathrm{mg}$ or higher. In lower doses, it was slightly less potent than progesterone. In a dose of $31 \mu \mathrm{g}$ per animal, two of four animals treated with progesterone ovulated, whereas none of the animals treated with pregn-5-ene-3,20-dione ovulated. It may be that pregn-5-ene-3,20-dione need not be converted into progesterone for its facilitatory activity, since its effect is equal to that of progesterone. On the other hand, in the light of the high turnover numbers associated with the $\Delta^{4-5}$ isomerase, it is possible that pregn-5-ene-3,20-dione is rapidly converted to progesterone. Additionally, if an increase in the activity of $\Delta^{4-5}$ isomerase in PB-treated animals is postulated, then an accelerated conversion of pregn-5-ene-3,20-dione into progesterone would result and ovulation would be potentiated.

In the animals treated with $\mathrm{PB}$, increased pregnenolone and decreased progesterone were found (Meyer et al., 1971; Norman \& Greenwald, 1971; Karavolas et al., 1972). In animals treated with PB, the conversion of pregnenolone to progesterone is inhibited and the optimal ratio of oestrogen:progesterone for ovulation is not attained. Inhibitors of enzymes that catalyse reactions during steroidogenesis in the ovary have been investigated recently and found to have an inhibitory effect on ovulation (Lipner \& Greep, 1971; Lipner \& Wendelken, 1971). On the basis of the present experiments, it is suggested that the ovulation which occurs $24 \mathrm{hr}$ after the PB-induced block, is due to the conversion of accumulated pregnenolone to progesterone as the effect of the drug is attenuated.

\section{AGKNOWLEDGMENTS}

This investigation was supported by the Ford Foundation Grant No. 630-0505A. H.J.K. was a Research Career Development Awardee, NICHD No. 1 K4HD-70, 006-01.

\section{REFERENGES}

Armura, A. \& Schally, A. V. (1970) Progesterone suppression of LH-releasing hormone-induced stimulation of LH release in rats. Endocrinology, 87, 653.

ARMSTRONG, D. T. \& King, E. R. (1971) Uterine progesterone metabolism and progestational response: effects of estrogens and prolactin. Endocrinology, 89, 191.

Bosley, G. G. \& LEAVITT, W. W. (1972) Specificity of progesterone action during the preovulatory period in the cyclic hamster. Fedn Proc. Fedn Am. Socs exp. Biol. 31, 257, Abstr.

Caligaris, L., Astrada, J. J. \& Taleisnik, S. (1968) Stimulating and inhibiting effects of progesterone on the release of luteinizing hormone. Acta endocr., Copenh. 59, 177. 
Gheatum, S. G., Douville, A. W. \& Warren, J. C. (1967) Site specificity of bovine adrenal $3 \beta-$ hydroxysteroid dehydrogenase and $\Delta^{5}$-3-ketosteroid isomerase. Biochim. biophys. Acta, $137,172$.

Cheatum, S. G. \& Warren, J. C. (1960) Purification and properties of $3 \beta$-hydroxysteroid dehydrogenase and $\Delta^{5}$-3-ketosteroid isomerase from bovine corpora lutea. Biochim. biophys. Acta, 122,1 .

Cheng, Y. \& Karavolas, H. J. (1973) Conversion of progesterone to $5 \alpha$-pregnane-3,20-dione and $3 \alpha$-hydroxy-5 $\alpha$-pregnan-20-one by rat medial basal hypothalami and the effects of estradiol and stage of estrous cycle on the conversion. Endocrinology, 93, 157.

EveretT, J. W. \& SAwYer, C. H. (1950) A 24-hour periodicity in the "LH-release apparatus" of female rats, disclosed by barbiturate sedation. Endocrinology, 47, 198.

Ewald, W., Werbin, H. \& Chaikoff, I. L. (1964) Partial separation of beef adrenal $\Delta^{5}$-3-ketosteroid isomerases: androst-5-ene-3,17-dione isomerase and pregn-5-ene-3,20-dione isomerase. Steroids, 4, 759 .

Gupta, C. \& Karavolas, H. J. (1973) Lowered ovarian conversion of ${ }^{14}$ G-pregnenolone to progesterone and other metabolites during phenobarbital (PB) block of PMS-induced ovulation in immature rats: inhibition of $3 \beta$-hydroxysteroid dehydrogenation. Endocrinology, 92, 117.

Karavolas, H. J., Gupta, C. \& Meyer, R. K. (1972) Steroid biosynthesis and metabolism during phenobarbital (PB) block of PMS-induced ovulation in immature rats. Endocrinology, 91, 157.

Karavolas, H. J. \& Herf, S. M. (1971) Conversion of progesterone by rat medial basal hypothalamic tissue to $5 \alpha$-pregnane-3,20-dione. Endocrinology, 89, 940.

LipNer, H. \& Greep, R. O. (1971) Inhibition of steroidogenesis at various sites in the biosynthetic pathway in relation to induced ovulation. Endocrinology, 88, 602 .

LIPNER, H. \& WENDELKEN, L. (1971) Inhibition of ovulation by inhibition of steroidogenesis in immature rats. Proc. Soc. exp. Biol. Med. 136, 1141.

McCormack, G. E. \& MEyer, R. K. (1962) Ovulating hormone release in gonadotrophin treated immature rats. Proc. Soc. exp. Biol. Med. 110, 343.

McCormack, C. E. \& Meyer, R. K. (1964) Minimal age for induction of ovulation with progesterone in rats: evidence for neural control. Endocrinology, 74, 793.

Meyer, R. K., Karavolas, H. J., Klausing, M. \& Norgard, D. W. (1971) Blood progesterone and pregnenolone levels during phenobarbital (PB) block of PMS-induced ovulation in immature rats. Endocrinology, 88, 983.

Norman, R. L. \& Greenwald, G. S. (1971) Effect of phenobarbital, hypophysectomy and Xirradiation on preovulatory progesterone levels in the cyclic hamster. Endocrinology, 89, 598.

Strauss, W. F. \& MEyer, R. K. (1962) Neural timing of ovulation in immature rats treated with gonadotrophin. Science, $\mathcal{N} . \Upsilon .137,860$.

Swerdlofr, R. S., Jacobs, H. S. \& Odell, W. D. (1972) Synergistic role of progestogens in estrogen induction of LH and FSH surge. Endocrinology, 90, 1529.

WIEsT, W. G. (1963) In vitro metabolism of progesterone and $20 \alpha$-hydroxypregn-4-en-3-one by tissues of the female rat. Endocrinology, 73, 310.

YING, S. Y. (1969) The role of steroids in the regulation of gonadotropin-induced ovulation in immature rats. Ph.D. thesis, University of Wisconsin, Madison, Wisconsin.

YiNG, S. Y. \& MEYer, R. K. (1969a) Effect of progesterone on induced ovulation in immature rats. 7. Reprod. Fert. 20, 279.

YING, S. Y. \& MEYeR, R. K. (1969b) Dose-dependent pregnant mare's serum-induced ovulation in immature rats. Proc, Soc. exp, Biol. Med. 130, 43.

YING, S. Y. \& MEYeR, R. K. (1969c) Effects of steroids on neuropharmacologic blockade of ovulation in pregnant mare's serum (PMS)-primed immature rats. Endocrinology, 84, 1466.

ZarRow, M. X. \& Brown-GraNT, K. (1964) Inhibition of ovulation in the gonadotrophin-treated immature rat by chlorpromazine. 7. Endocr. 30, 87.

Zarrow, M. X. \& Gallo, R. V. (1969) Action of progesterone on PMS-induced ovulation in the immature rat. Endocrinology, 84, 1274.

Zarrow, M. X. \& Hurlbut, E. G. (1967) Inhibition and facilitation of PMS-induced ovulation in the immature rat following treatment with progesterone. Endocrinology, 80, 735. 